\title{
Analisis penyimpangan konversi energi listrik menjadi kalor pada perangkat eksperimen Hukum Joule
}

\author{
H Kunlestiowati \\ Politeknik Negeri Bandung \\ Jln. Geger Kalong Hilir, Ds Ciwaruga, Bandung \\ Surat-e: kunpolban@yahoo.co.id
}

Perubahan bentuk energi listrik menjadi kalor dikenal dengan Hukum Joule, yang menyatakan bahwa energi listrik dapat diubah menjadi energi panas. Penelitian ini bertujuan untuk mencari penyimpangan kalor yang dihasilkan dari energi listrik menggunakan perangkat eksperimen Hukum Joule. Pada penelitian ini air dipanaskan dalam kalorimeter, dengan arus, tegangan listrik dan waktu pemanasan dan pendinginan dibuat tetap. Hasil pengamatan menggunakan alat Joule meter menunjukkan adanya perbedaan yang signifikan antara energi panas pada air I00 gram dengan nilai rata-rata energi panas 2736,72 J dan air I50 gram dengan nilai rata-rata energi panas 265I,04 J. Grafik antara energi panas terhadap energi listrik menunjukkan perbedaan gradien pada suhu $23,5{ }^{\circ} \mathrm{C}$ yaitu $0,9 \mathrm{I}$ untuk air I00 gram dan 0,99 untuk air I50 gram, sedangkan pada suhu $25,5^{\circ} \mathrm{C}$ untuk air $\mathrm{I} 00$ gram dan $\mathrm{I} 50$ gram gradiennya adalah 0,99 dan 0,64 . Hasil tersebut menunjukkan penyimpangan konversi energi listrik menjadi kalor pada perangkat eksperimen hukum Joule.

The transformation of electrical energy into heat energy is known as Joule's Law, which states that electrical energy can be converted into heat energy. This study aims to find the distortion of heat generated by electrical energy using the Joule Law experiment device. In this study, water is heated in the calorimeter, with constant current, electric voltage and heating and cooling times. The result of observation using Joule meter shows significant difference between heat energy in IOO grams water with the average value of heat energy $2736.72 \mathrm{~J}$ and 150 grams water with the average value of heat energy 265I.04 J. The graph of heat energy towards electrical energy shows gradient difference at temperature $23.5^{\circ} \mathrm{C}$ that is $0,9 \mathrm{I}$ for $\mathrm{IOO}$ grams water and 0,99 for I50 grams water, while at temperature $25.5{ }^{\circ} \mathrm{C}$ for I00 grams and I50 grams water the gradient are 0.99 and 0.64 . The result of this study shows the deviation of the conversion of electrical energy into heat in the Joule law experiment device.

Kata kunci: Hukum Joule, Kalor, Energi Listrik

\section{Pendahuluan}

Konversi energi merupakan kondisi fisis perubahan bentuk energi dari satu bentuk menjadi bentuk yang lain. Salah satu contoh konversi energi adalah energi listrik dapat berubah menjadi energi panas (kalor), hal ini harus memperhatikan kesetaraan antara satuan energi listrik dan kalor, kesetaraan tersebut adalah bahwa I joule $=0,24$ kalori. Bilangan 0,24 merupakan nilai kesetaraan antara joule dan kalori. Salah satu alat untuk mengubah energi listrik menjadi kalor dilengkapi dengan elemen pemanas, dialiri arus listrik, yaitu aliran elektron yang mengalir melalui elemen pemanas, sehingga dapat mengubah energi listrik menjadi kalor. Kalor merupakan kemampuan yang terjadi akibat adanya perubahan suhu, yang banyak dimanfaatkan dalam kehidupan sehari-hari [I,2]. Dalam kenyataan, pada umumnya yang terjadi adalah besar energi panas yang dihasilkan tidak sebesar energi listrik, karena sebagian energi dilepas ke sisitem [I]. Agar jumlah energi panas yang dihasilkan sama dengan energi listrik perlu dilakukan optimasi melalui faktor/besaran fisis yang mempengaruhi jumlah energi listrik dan kalor, harapannya agar perbedaan jumlah kalor yang dihasilkan dengan energi listrik tidak terlalu jauh, atau dapat dikatakan penyimpangan hukum Joule tidak terlalu besar. Pada penelitian ini dilakukan analisis penyimpangan konversi energi listrik menjadi kalor pada perangkat eksperimen 
hukum joule, dengan mengamati besaran yang mempengaruhi energi listrik maupun kalor

Sejauh ini percobaan yang sudah dilakukan menggunakan alat eksperimen hukum joule, belum mendapatkan hasil yang optimum, yaitu besar kalor yang dihasilkan belum sama dengan energi listrik artinya prinsip hukum kekekalan energi belum dapat terbukti. Dengan demikian timbul permasalahan untuk mengkaji besaran-besaran yang berpengaruh terhadap energi listrik dan kalor. Kondisi ini mendorong perlu adanya kegiatan penelitian sebagai masukan bahan kajian berupa analisis besaran-besaran yang berpengaruh terhadap energi listrik dan kalor. Besaran yang akan dikaji dibatasi hanya massa air yang diubah, besaran lain yaitu: arus, tegangan, waktu pemanasan dan waktu pendinginan dibuat tetap.

\section{Kajian Pustaka}

Energi merupakan besaran yang kekal, artinya energi tidak dapat diciptakan dan dimusnahkan, tetapi dapat diubah dari suatu bentuk satu ke bentuk yang lain namun tidak merubah jumlah atau besar energi secara keseluruhan[3]. selanjutnya yang akan dibahas adalah kalor dan energi listrik. kalor adalah energi yang timbul saat terjadinya perubahan suhu benda, dan menjalar dari bagian yang panas ke bagian yang dingin. energi listrik adalah energi yang ditimbulkan oleh benda yang bermuatan listrik. muatan listrik yang diam (statis) menimbulkan energi potensial listrik, sedangkan muatan listrik yang bergerak (dinamis) menimbulkan arus listrik dan energi magnet. arus listrik adalah banyaknya muatan listrik yang mengalir tiap satuan waktu. tegangan listrik adalah perbedaan potensial listrik antara dua titik dalam rangkaian listrik dan dinyatakan dalam satuan volt. energi listrik adalah energi akhir yang dibutuhkan bagi peralatan listrik untuk menggerakkan motor, lampu penerangan, memanaskan, mendinginkan ataupun untuk menggerakkan kembali suatu peralatan mekanik untuk menghasilkan bentuk energi lain. [I,3,5].

Jika beda potensial $V$, kuat arus $I$, dan waktunya t maka persamaan untuk energi listrik adalah :

$$
W=V . I . t
$$

dengan,

$V=$ beda potensial (volt)

$I=$ kuat arus (ampere)

$t=$ waktu (sekon)

$W=$ energi yang dilepaskan oleh sumber tegangan (joule)

Kalor merupakan satu bentuk energi yang berpindah akibat perbedaan suhu. Panas bergerak dari daerah bersuhu tinggi ke daerah bersuhu rendah. Ketika dua benda dengan suhu berbeda bersentuhan, maka akan terjadi pertukaran energi internal sampai suhu kedua benda tersebut seimbang[3,5]. Jumlah panas secara matematis dapat ditulis sabagai berikut
$Q=m c \Delta T$

$Q=$ banyaknya kalor (jumlah panas) dalam joule

$m=$ adalah massa benda dalam $\mathrm{kg}$

$c=$ adalah kalor jenis dalam joule $/ \mathrm{kg}{ }^{\circ} \mathrm{C}$, dan

$\Delta T=$ adalah besarnya perubahan suhu dalam ${ }^{\circ} \mathrm{C}$.

Perubahan suhu $(\Delta T)$ untuk menghasilkan kalor, memenuhi persamaan Hukum Pendinginan Newton yang menyatakan bahwa laju perubahan pendinginan suhu suatu benda sebanding dengan perbedaan antara suhu sendiri dan suhu ambien (yaitu suhu sekitarnya). Hukum Newton membuat pernyataan tentang tingkat sesaat perubahan suhu $[2,4]$, yaitu

$$
\frac{d T}{d t}=k\left(T-T_{0}\right)
$$

Besaran $\mathrm{dT} / \mathrm{dt}$ merupakan fungsi temperatur (suhu) terhadap waktu, $k$ adalah konstanta, $T$ adalah suhu pada saat $\mathrm{t}$ sekon, dan $\mathrm{T}_{0}$ adalah suhu pada saat $\mathrm{t}=0$ sekon. Nilai $k$ tidak diketahui, namun nilainya bisa didapat dengan menurunkan persamaan diatas.(nilai dari $\mathrm{k}$ dapat berharga $-\mathrm{k}$ dan $+\mathrm{k}$, hal ini dapat ditentukan dengan cara: apabila suhunya mengalami kenaikan nilai yang dipakai adalah $+\mathrm{k}$, sebaliknya bila suhu mengalami penurunan maka nilainya adalah $-\mathrm{k}$ ).

Berikut adalah grafik dari nilai k.[4]

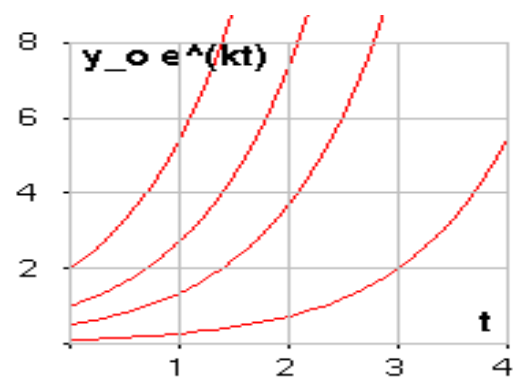

Gambar I. Peningkatan Suhu (+k)

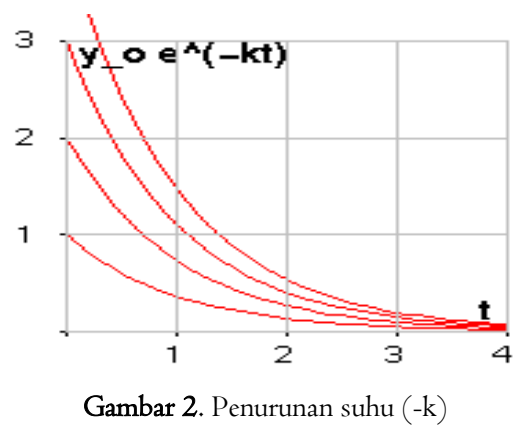

Hukum Joule merupakan salah satu contoh dari prinsip hukum kekekalan energi, yang menyatakan bahwa energi listrik yang terjadi pada kawat yang dialiri arus listrik dapat di ubah menjadi kalor, berdasarkan pernyataan ini seharusnya $[\mathrm{I}, 3,5]$

$$
W=Q
$$




\section{Metode Penelitian/Eksperimen}

Metode penelitian adalah metode analisis deskriptif. Dalam pengambilan data alat yang digunakan seperti pada Gambar 3 dan Gambar 4.

Uji statistik dilakukan untuk pengambilan data pertama, yaitu :

Satu besaran yang berpengaruh terhadap kalor yaitu massa air I50 gram dan I50 gram, diamatai sebanyak 25 kali. Sedangkan besaran yang berpengaruh terhadap energi listrik dibuat tetap, kumparan diberi arus $3 \mathrm{~A}$, tegangan listrik 8 Volt dengan waktu pemanasan I20 detik, dan waktu pendinganan 240 detik.

Untuk membandingkan pengaruh massa air terhadap kalor hasil uji statistik, dilakukan pengambilan data kembali menggunakan joule meter, grafik kalor terhadap energi listrik dibuat berbantuan program Octave.

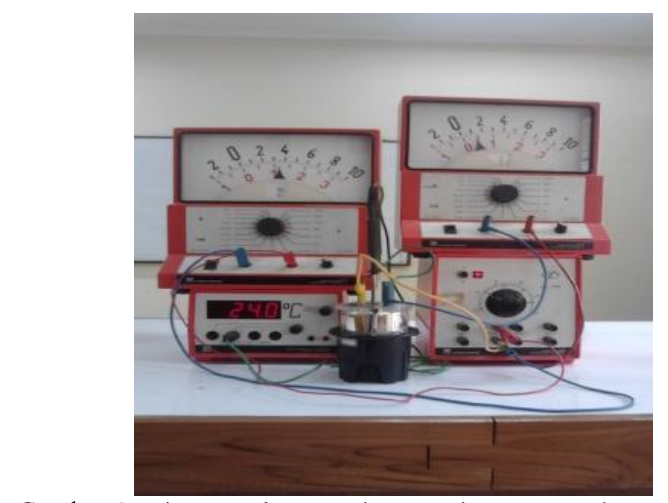

Gambar 3. Alat Percobaan Hukum Joule menggunakan Voltmeter dan Amperemeter

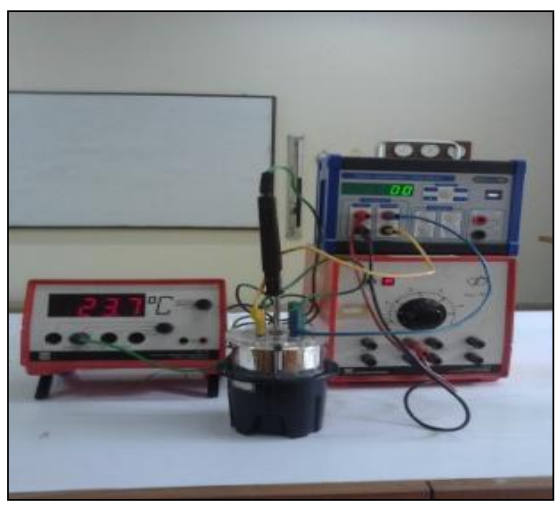

Gambar 4. Alat percobaan Hukum Joule menggunakan Joulemeter

\section{Hasil Penelitian dan Pembahasan}

\section{Teknik analisis deskriptif}

Teknik analisis deskriptif bertujuan untuk menjelaskan mengenai keseluruhan data, dimana dapat dilihat nilai minimum, nilai maksimum, dan rata-rata dari masingmasing data penelitian. Berikut disajikan deskriptif dari masing-masing data penelitian. Tabel I menggambarkan perubahan suhu untuk pemanasan air sebanyak 100 gram selama 120 detik dan pendinginan selama 240 detik yang dilakukan sebanyak 25 kali pengamatan. Kalor yang dihasilkan merupakan hasil perkalian massa, kalor jenis $\left(4,2 \mathrm{~J} /\right.$ gram $\left.{ }^{\circ} \mathrm{C}\right)$ dan perubahan suhu $(\Delta \mathrm{T})$ air, yang dalam perhitungannya menggunakan persamaan (III).

Berdasarkan Output SPSS, dapat diketahui nilai maksimum, nilai minimum, dan rata-rata perubahan suhu untuk massa air $\mathrm{IOO}$ gr, berturut turut $7,522^{\circ} \mathrm{C} ; 5,9 \mathrm{I} 8$ ${ }^{\circ} \mathrm{C}$; dan rata-rata perubahan suhu sebesar $6,516{ }^{\circ} \mathrm{C}$.

Untuk massa air I50 gram, berdasarkan output SPSS pada Tabel 2 dengan nilai minimum, nilai maksimum, dan rata-rata perubahan suhu berturut turut $4.620^{\circ} \mathrm{C}$, $3.818^{\circ} \mathrm{C}$; dan $4.208^{\circ} \mathrm{C}$.

Tabel I. Perubahan suhu untuk massa air 100 gram

\begin{tabular}{|c|c|c|}
\hline No & Perubahan suhu $\left(\mathrm{C}^{\circ}\right)$ & Keterangan \\
\hline I & 6,2315 & \\
\hline 2 & 7,0353 & \\
\hline 3 & 6,4287 & \\
\hline 4 & 6,3331 & \\
\hline 5 & 6,1275 & \\
\hline 6 & 6,332 & \\
\hline 7 & 6,1221 & \\
\hline 8 & 6,2184 & \\
\hline 9 & 6,122 & \\
\hline I0 & 6,2179 & \\
\hline II & 5,918 & \\
\hline $\mathrm{I} 2$ & 6,024 & \\
\hline $\mathrm{I} 3$ & $7,025 \mathrm{I}$ & \\
\hline $\mathrm{I} 4$ & $7,22 \mathrm{I} 2$ & \\
\hline I5 & 7,5218 & \\
\hline 16 & 6,3243 & \\
\hline I7 & 7,4264 & \\
\hline I8 & 6,9255 & \\
\hline 19 & 6,5193 & \\
\hline 20 & 6,4152 & \\
\hline $2 \mathrm{I}$ & 6,7299 & \\
\hline 22 & 6,5234 & \\
\hline 23 & 6,5193 & \\
\hline 24 & 6,4253 & \\
\hline 25 & 6,2185 & \\
\hline 26 & 7.522 & Suhu maksimum \\
\hline 27 & 5.918 & Suhu minimum \\
\hline 28 & 6.516 & Suhu rata-rata \\
\hline
\end{tabular}

Dari Tabel I jika dibuat grafik, untuk perubahan suhu dapat dilihat pada Gambar V

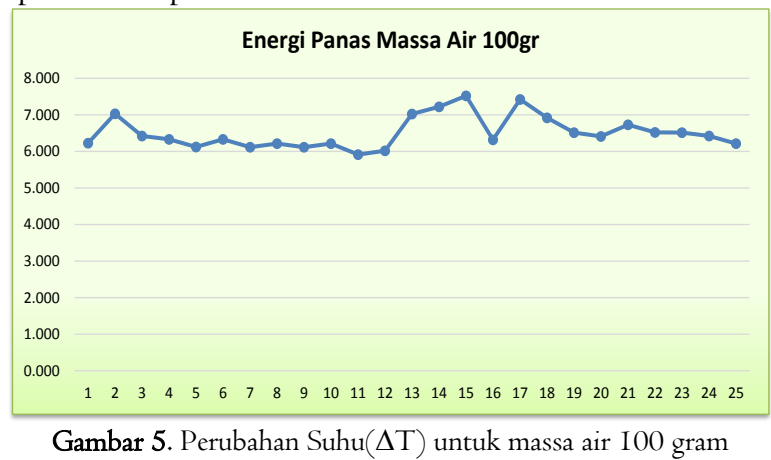

Gambar 5. Perubahan Suhu( $(\Delta \mathrm{T})$ untuk massa air 100 gram 
Untuk massa air 150 gram, berdasarkan output SPSS pada Tabel 2 dengan nilai minimum, nilai maksimum, dan rata-rata perubahan suhu berturut turut $4.620^{\circ} \mathrm{C}$, $3.818^{\circ} \mathrm{C}$; dan $4.208^{\circ} \mathrm{C}$

Tabel 2. Perubahan suhu untuk massa air 150 gram

\begin{tabular}{|c|c|c|}
\hline No & Perubahan suhu $\left(\mathrm{C}^{\circ}\right)$ & Keterangan \\
\hline $\mathrm{I}$ & 4,1064 & \\
\hline 2 & 4,IIO8 & \\
\hline 3 & 4,2176 & \\
\hline 4 & $4,3 \mathrm{II} 4$ & \\
\hline 5 & 4,1097 & \\
\hline 6 & $4,3 \mathrm{I} 28$ & \\
\hline 7 & $4,4 \mathrm{I} 3$ & \\
\hline 8 & $4,5 \mathrm{I} 33$ & \\
\hline 9 & $4,4 \mathrm{I} 62$ & \\
\hline I0 & 4,4076 & \\
\hline I I & 3,9126 & \\
\hline $\mathrm{I} 2$ & 3,9356 & \\
\hline I3 & 4,2234 & \\
\hline I4 & $4,2 \mathrm{I} 7 \mathrm{I}$ & \\
\hline I5 & 3,9177 & \\
\hline 16 & $4,4 \mathrm{I} 64$ & \\
\hline 17 & $4,2 \mathrm{IOI}$ & \\
\hline 18 & 4,4262 & \\
\hline 19 & 4,0233 & \\
\hline 20 & 3,919I & \\
\hline $2 \mathrm{I}$ & 4,6197 & \\
\hline 22 & 4,6152 & \\
\hline 23 & $4, \mathrm{II} 75$ & \\
\hline 24 & 3,9I4I & \\
\hline 25 & 3,8182 & \\
\hline 26 & 4.620 & Suhu maksimum \\
\hline 27 & 3.818 & Suhu minimum \\
\hline 28 & 4.208 & Suhu rata-rata \\
\hline
\end{tabular}

Dari Tabel 2 jika dibuat grafik, untuk perubahan suhu dapat dilihat pada Gambar 6

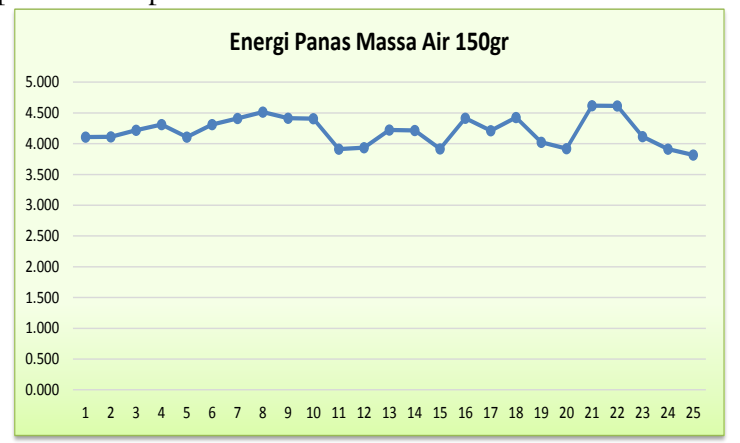

Gambar 6. Perubahan Suhu $(\Delta \mathrm{T})$ untuk massa air 100 gram

\section{Uji Perbandingan Statistik Uji Normalitas}

Uji normalitas yang digunakan adalah metode Kolmogorov-Smirnov. Berikut disajikan secara lengkap perhitungan hasil uji normalitas data perubahan suhu untuk massa air I00 gram dan I50 gram, dengan masingmasing perubahan suhu nya.
Tabel 3. Uji Normalitas data perubahan suhu yang menghasilkan kalor untuk air I00 gram dan I50gram

One-Sample Kolmogorov-Smirnov Test

\begin{tabular}{|ll|r|r|}
\hline & $\begin{array}{c}\text { Perubahan T } \\
\text { (Energi } \\
\text { Panas) } \\
\text { Massa Air } \\
100 \mathrm{gr}\end{array}$ & $\begin{array}{c}\text { Perubahan T } \\
\text { (Energi } \\
\text { Panas) } \\
\text { Massa Air } \\
150 \mathrm{gr}\end{array}$ \\
\hline $\mathrm{N}$ & 25 & 25 \\
Normal Parameters ${ }^{\text {a,b }}$ & Mean & 6.516228 & 4.208200 \\
& Std. Dev iation & .4386569 & .2332845 \\
Most Extreme & Absolute & .213 & .124 \\
Diff erences & Positive & .213 & .119 \\
& Negative & -.104 & -.124 \\
Kolmogorov-Smirnov Z & 1.067 & .618 \\
Asy mp. Sig. (2-tailed) & .205 & .839 \\
\hline \multicolumn{2}{c|}{ a. Test distribution is Normal. } & & \\
\multicolumn{2}{c|}{ b. Calculated from data. } & &
\end{tabular}

Dari perhitungan diperoleh nilai Asymp.Sig.(2-tailed) sebesar 0.205 untuk data perubahan suhu massa air 100 gram, dan sebesar 0.839 untuk massa air 150 gram. Dikarenakan nilai Asymp.Sig.(2-tailed) data perubahan suhu massa air I00 gram dan I50 gram lebih besar dari alpha (Asymp.Sig.> 0,05), dapat disimpulkan bahwa data perubahan suhu massa air I00 gram dan I50 gram berdistribusi normal.

\section{Uji Homogenitas}

Uji homogenitas yang digunakan adalah metode Levene-test. Berikut disajikan secara lengkap perhitungan hasil uji homogenitas data perubahan suhu massa air 100 gram dan massa air I50 gram. Dari perhitungan diperoleh nilai $p$-valuesebesar 0.053. Dikarenakan nilai $p$-value lebih besar dari pada alpha (Asymp.Sig.> 0,05) atau $0.053>0.05$, dapat disimpulkan bahwa data perubahan suhu air I00 gram dan I50 gram homogen.

Tabel 4. Uji Homogenitas data peruahan suhu I00 gr dan I50 gr

\section{Test of Homogeneity of Variances}

Perubahan T (Energi Panas)
\begin{tabular}{|r|r|r|c|}
\hline $\begin{array}{r}\text { Levene } \\
\text { Statistic }\end{array}$ & df 1 & df 2 & Sig. \\
\hline 6.584 & 1 & 48 & .053 \\
\hline
\end{tabular}

Dari hasil uji normalitas di atas, dapat diketahui bahwa tidak terdapat pelanggaran terhadap asumsi pengujian. Oleh sebab itu pengujian akan dilakukan menggunakan metode parametrik, yaitu menggunakan Independent ttest. Uji Homogenitas tersebut hasilnya terdapat pada Tabel 4. 


\section{Independent t-test}

Independent t-test adalah salah satu metode pengujian hipotesis dimana data yang digunakan bebas (tidak berpasangan) dan berdistribusi normal.

Pengujian hipotesis:

$\mathrm{H}_{0} \quad$ :tidak terdapat perbedaan yang signifikan antara energi panas (kalor) dari massa air IOOgr dan kalor dari massa air I50gr;

$\mathrm{H}_{\mathrm{I}} \quad$ :terdapat perbedaan yang signifikan antara energi panas dari massa air IOOgr dan energi panas dari massa air I50gr.

$\alpha: 5 \%$

Dengan bantuan aplikasi Program SPSS versi 19.0 didapat output hasil perhitungan seperti pada Tabel.V

Berdasarkan Tabel V. di atas, diketahui bahwa nilai pvalue yang diperoleh sebesar 0,000. Jika dibandingkan dengan alpha 5\%, nilai tersebut lebih kecil $(0,000<$ $0,05)$ yang menyatakan $H_{0}$ ditolak, yang berarti terdapat perbedaan yang signifikan antara kalor dari air IOO gram dan air I50 gram, wlaupun dengan energi listrik yang sama

Tabel 5. Perbandingan kalor dari air I00 gr dan air I50 gr

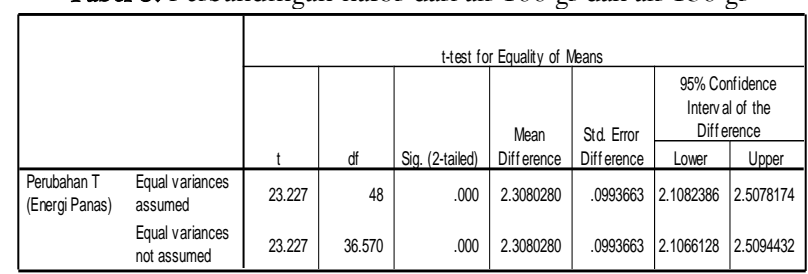

\section{Uji perbandingan Alat}

Air I00 gram dan 150 gram dipanaskan selama I20 detik keduanya dipanaskan dan energinya dibaca melalui Joule meter, hasilnya seperti Tabel 6 dan Tabel 7.

Tabel 6. Perubahan suhu dan energi setiap I5 detik air 100 gram

\begin{tabular}{ccccc}
\multicolumn{5}{c}{$\left(\mathrm{Tr}=23,5^{\circ} \mathrm{C}\right)$} \\
\hline No & $\mathbf{t}($ detik) & $\mathrm{T}\left({ }^{\circ} \mathrm{C}\right)$ & $\mathbf{Q}$ (joule) & $\mathrm{W}$ (joule) \\
\hline 2 & 0 & 22,7 & 0 & 0 \\
3 & $\mathrm{I} 5$ & 23 & $\mathrm{I} 26$ & 368 \\
4 & 30 & 24,3 & 672 & 764 \\
5 & 65 & $25, \mathrm{I}$ & $\mathrm{I} 008$ & $\mathrm{II} 56$ \\
6 & 75 & 26 & $\mathrm{I} 386$ & 1529 \\
7 & 90 & 27,7 & $2 \mathrm{I00}$ & $235 \mathrm{I}$ \\
8 & $\mathrm{I} 05$ & 28,5 & 2436 & $275 \mathrm{I}$ \\
9 & $\mathrm{I} 20$ & 29,3 & 2772 & $3 \mathrm{I} 47$ \\
\hline
\end{tabular}

Tabel 7. Perubahan suhu dan energi setiap 15 detik air $=150$ gram $\left(\operatorname{Tr}=23,5^{\circ} \mathrm{C}\right)$

\begin{tabular}{ccccc}
\hline No & $\boldsymbol{t}$ (detik) & $\mathrm{T}\left({ }^{\circ} \mathrm{C}\right)$ & $\mathrm{Q}$ (joule) & $\mathrm{W}$ (joule) \\
\hline $\mathrm{I}$ & 0 & 22,5 & 0 & 0 \\
2 & $\mathrm{I} 5$ & $23, \mathrm{I}$ & 378 & 375 \\
3 & 30 & 23,7 & 756 & 754 \\
4 & 45 & 24,3 & $\mathrm{II} 34$ & $\mathrm{I} 136$ \\
5 & 60 & 24,9 & 1512 & 1518 \\
6 & 75 & 25,5 & 1890 & 1906 \\
7 & 90 & $26, \mathrm{I}$ & 2268 & 2298 \\
8 & $\mathrm{I} 05$ & 26,8 & 2709 & 2686 \\
9 & $\mathrm{I} 20$ & 27,3 & 3024 & 3077 \\
\hline
\end{tabular}

Berdasarkan Tabel VI dan VII , jika dibuat grafik hubungan antara kalor (Q) dan energi listrik (W) berbantuan program Oktave dapat ditunjukkan pada Gambar VII

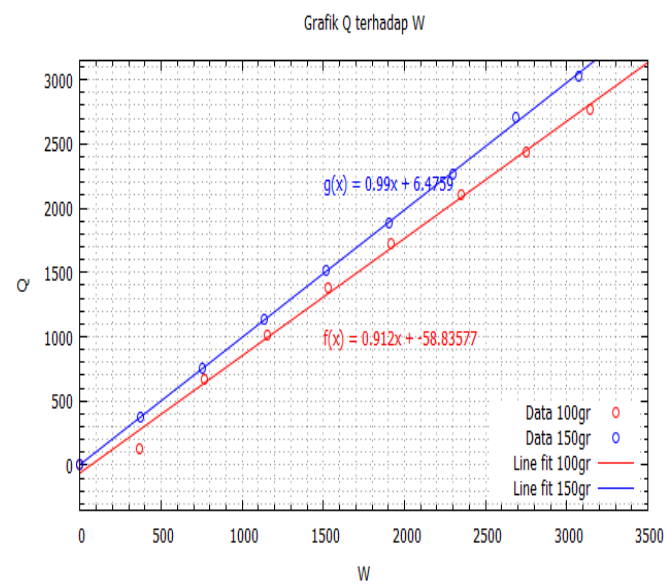

Gambar 7. Hubungan kalor dan energi listrik pada suhu ruang $23,5^{\circ} \mathrm{C}$

Hasil pengamatan air 100 gram pada tabel 8 dan air I50 gram pada tabel 9 untuk suhu ruang $25,5^{\circ} \mathrm{C}$.

Dengan cara seperti yang sudah dilakukan sebelumnya, data ditabelkan , di cari besar kalor dan energi listrik diamati melalui Joule meter, maka diperoleh hubungan antara kalor dan energi listrik seperti pada Gambar 8 .

Gambar 7 dan Gambar 8 memperlihatkan adanya perbedaan gradien antara air 100 gram dan 150 gram. Gradien untuk 100 gram dan 150 gram di suhu ruang $23,5^{\circ} \mathrm{C}$ adalah $0,9 \mathrm{I}$ dan 0,99 . Pada suhu ruang $25,5^{\circ} \mathrm{C}$ gradiennya adalah 0,99 dan 0,64 . Hal ini menunjukkan bahwa dengan massa air yang berbeda dan energi listrik yang sama, akan diperoleh kalor yang berbeda, seperti uji statistik diatas ada perbedaan yang signifikan. Sedangkan prinsip Hukum Joule, kalor yang dihasilkan sama dengan energi listrik yang diberikan untuk memanaskan zat, atau perbandingan antara jumlah kalor dan energi listrik adalah satu. Dari hasil ini perlu dikaji faktor lain yang mempegaruhi proses konversi energi pada perangkat eksperimen hukum Joule tersebut 
Tabel 8. Perubahan suhu dan energi setiap I5 detik air $\mathrm{IOO} \operatorname{gram}\left(\mathrm{Tr}=25,5^{\circ} \mathrm{C}\right)$

\begin{tabular}{ccccc}
\hline No & $\mathbf{t}$ (detik) & $\mathrm{T}\left({ }^{\circ} \mathrm{C}\right)$ & $\mathrm{Q}$ (Joule) & $\mathrm{W}$ (Joule) \\
\hline $\mathrm{I}$ & 0 & 24,3 & 0 & 0 \\
2 & $\mathrm{I} 5$ & 24,6 & $\mathrm{I} 26$ & 398 \\
3 & 30 & 25,3 & 420 & 795 \\
4 & 45 & 25,8 & 630 & $\mathrm{I} 175$ \\
5 & 60 & 26,6 & 966 & $\mathrm{I} 590$ \\
6 & 75 & 27,2 & $\mathrm{I} 218$ & 2006 \\
7 & 90 & 27,9 & $\mathrm{I} 5 \mathrm{I} 2$ & 2445 \\
8 & 105 & 28,5 & 1764 & 2854 \\
9 & 120 & $29, \mathrm{I}$ & 2016 & 3274 \\
\hline
\end{tabular}

Tabel 9. Perubahan suhu dan energi setiap I5 detik air 150 gram $\left(\operatorname{Tr}=25,5^{\circ} \mathrm{C}\right)$

\begin{tabular}{ccccc}
\hline No & $\mathbf{t}$ (detik) & $\mathrm{T}\left({ }^{\circ} \mathrm{C}\right)$ & $\mathrm{Q}$ (Joule) & $\mathrm{W}$ (Joule) \\
\hline $\mathrm{I}$ & 0 & 23,8 & 0 & 0 \\
2 & $\mathrm{I} 5$ & 24,4 & 378 & 406 \\
3 & 30 & 24,9 & 693 & $8 \mathrm{I} 4$ \\
4 & 45 & 26,5 & $\mathrm{I} 70 \mathrm{I}$ & 1203 \\
5 & 60 & 26,2 & $\mathrm{I} 5 \mathrm{I} 2$ & 1647 \\
6 & 75 & 26,8 & 1890 & 2042 \\
7 & 90 & 27,4 & 2268 & 2498 \\
8 & 105 & 28,4 & 2898 & 2922 \\
9 & 120 & 29,4 & 3528 & 3339 \\
\hline
\end{tabular}

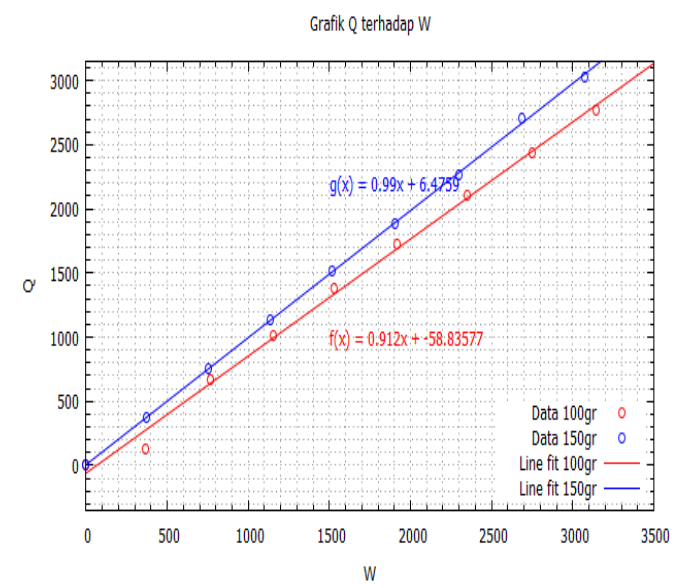

Gambar 8. Hubungan kalor dan energi listrik pada suhu ruang $25,5^{\circ} \mathrm{C}$

\section{Kesimpulan}

Berdasarkan paparan hasil analisis dan pembahasan sebagaimana yang telah diuraikan diatas, dapat disimpulkan bahwa massa air berpengaruh terhadap besar kalor, perbedaan massa air menyebabkan perbedaan kalor yang dihasilkan untuk sumber energi listrik yang sama. Hasil ini membuktikan adanya penyimpangan konversi energi listrik menjadi kalor pada perangkat eksperimen Hukum Joule. Berdasarkan perhitungan, grafik dan uji statistik seperti yang diuraikan pada hasil dan pembahasan terdapat kesamaan hasil. Pada dasarnya banyak faktor yang mmpengaruhi prinsip konversi energi dari energi listrik menjadi energi panas (kalor).

Penelitian ini belum komprehensif, karena hanya satu besaran (satu variable) yang baru diamati, yaitu perubahan massa air yang dipanaskan. Perlu dilakukan penelitian lebih lanjut yaitu mengukur besaran-besaran lain yang berpengaruh terhadap prinsip konversi energi melalui perangkat hukum Joule

\section{Ucapan Terimakasih}

Penulis mengucapkan terima kasih kepada UPPM Politeknik Negeri Bandung yang telah memberikan Dana Panelitian Mandiri dan Kepala Laboratorium Fisika Terapan Politeknik Negeri Bandung yang telah memberikan kesempatan pada saya menggunakan Alat yang dibutuhkan, hingga penelitian ini dapat berlangsung dengan baik.

\section{Kepustakaan}

[I] Emma Carlson Berne "Heat Energy". The Rosen Publishing Group. p. I8. ISBN 978-I-4488-9886-2, p. I8, Januari 2013

[2] Kirsten R. Daehler; Jennifer Folsom; Mayumi Shinohara, "Making Sense of Science: Energy: For Teachers of Grades" 6 8. WestEd. ISBN 978-0-9I4409-78-6, Juni 2011

[3] Serway, R.A. dan Jewett, John W, Fisika Untuk Sains dan Teknik. Jakarta :Salemba Teknika, 2009

[4] Suryani dan Santosa, "Pengukuran Konstanta Pendinginan Newto",. Prosiding Seminar Nasional Sains dan Pendidikan Sains IX, Salatiga: UKSW, Vol 5, No.I, p. 386-390, 2014

[5] Tipler, Paul A,. Fisika untuk Sains dan Teknik. Jakarta: Erlangga, 2005 